\title{
Investigation of the Noncovalent Interactions Between Anti-Amyloid Agents and Amyloid $\beta$ Peptides by ESI-MS
}

\author{
Eric Martineau, ${ }^{\mathrm{a}, \mathrm{b}}$ Janna M. de Guzman, ${ }^{\mathrm{b}}$ Lioudmila Rodionova, ${ }^{\mathrm{b},+}$ \\ Xianqi Kong, ${ }^{\mathrm{b}}$ Paul M. Mayer, ${ }^{\mathrm{a}}$ and Ahmed M. Aman ${ }^{\mathrm{b}, *}$ \\ ${ }^{a}$ Chemistry Department, University of Ottawa, Ottawa, ON, Canada \\ b BELLUS Health Inc., 275 Armand-Frappier bvld., Laval, QC H7V 4A7, Canada
}

\begin{abstract}
This paper describes an efficient and reproducible screening method for identifying low molecular weight compounds that bind to amyloid $\beta$ peptides $(\mathrm{A} \beta)$ peptides using electrospray ionization mass spectrometry (ESI-MS). Low molecular weight compounds capable of interacting with soluble $\mathrm{A} \beta$ may be able to modulate/inhibit the $\mathrm{A} \beta$ aggregation process and serve as potential disease-modifying agents for AD. The present approach was used to rank the binding affinity of a library of compounds to $A \beta 1-40$ peptide. The results obtained show that low molecular weight compounds bind similarly to $\mathrm{A} \beta 1-42$, $\mathrm{A} \beta 1-40$, as well as $\mathrm{A} \beta 1-28$ peptides and they underline the critical role of $\mathrm{A} \beta$ peptide charge motif in binding at physiological pH. Finally, some elements of structure-activity relationship (SAR) involved in the binding affinity of homotaurine to soluble A $\beta$ peptides are discussed. (J Am Soc Mass Spectrom 2010, 21, 1506-1514) (C) 2010 Published by Elsevier Inc. on behalf of American Society for Mass Spectrometry
\end{abstract}

A lzheimer's disease (AD) is an incurable, progressive neurodegenerative condition leading to a gradual decline in cognitive function. Intracellular accumulation of neurofibrillary tangles consisting of tau protein and extracellular deposition of senile plaques composed of amyloid $\beta$ peptides $(\mathrm{A} \beta$ ) represent histopathologic hallmarks of $\mathrm{AD}[1-3] . \mathrm{A} \beta$ is considered to play a key role in $\mathrm{AD}$ pathogenesis [4] and the amyloid cascade hypothesis [5] stipulates that this results from the sequential $\beta$ - and $\gamma$-secretase cleavage of the amyloid precursor protein (APP) $[6,7]$. Several $\mathrm{A} \beta$ variants, including $\mathrm{A} \beta 1-40$ and $\mathrm{A} \beta 1-42$, produced by this amyloidogenic pathway are considered toxic under certain conditions. Nonpathologic low concentrations of $\mathrm{A} \beta$ are found in biological fluids throughout life. Abnormal metabolism such as reduced clearance or increased production leads to elevated $\mathrm{A} \beta$ concentration and aggregation [8]. At physiological $\mathrm{pH}$, soluble $\mathrm{A} \beta$ mainly adopts a random coil conformation [9] where peptides may interact to form intermolecular $\beta$-sheets leading to the production of intermediate species such as oligomers, fibrils, and eventually plaques [10, 11]. Whether or not the production of oligomers and fibrils occurs through a common mech-

Address reprint requests to Professor P. M. Mayer, Chemistry Department, University of Ottawa, 10 Marie Curie, Ottawa, ON K1N 6N5, Canada. E-mail: pmmayer@uottawa.ca

* Current address: Ontario Institute for Cancer Research, MaRS Centre, South Tower, 101 College Street, Suite 800, Toronto, ON M5G 0A3, Canada. + Current address: Aegera Therapeutics Inc., 810 Chemin du Golf, Montreal, QC H3E 1A8, Canada. anism is still debated [12]. Certain forms of oligomeric $\mathrm{A} \beta$ are believed to be toxic to neurons [13] while it has been shown that $\mathrm{A} \beta$ fibrils are harmful to cell membranes and elicit inflammatory responses from glial cells [14].

Proteoglycans (PGs) and glycosaminoglycans (GAGs) found in amyloid deposits contribute to $A \beta$ fibril formation by promoting the transition from a random coil to a $\beta$-sheet conformation $[15,16]$. It was hypothesized that by mimicking some GAGs structural properties, low molecular weight (LMW) compounds could interfere with the interaction of $A \beta$ with heparin sulphate proteoglycans of the basement membrane during the course of amyloid deposition [17]. One promising therapeutic perspective consists in identifying LMW compounds able to slow down or even stop these events in amyloidogenic pathway [18]. It was postulated that LMW compounds must first bind or interact with $A \beta$ to interfere in the aggregation and fibril formation. Efforts were invested in developing assays such as thioflavin $\mathrm{T}$ fluorescence (ThT) [19] and circular dichroism (CD) [20] to evaluate the interaction/binding of $\mathrm{A} \beta$ with LWM compounds. Very limited success has been achieved primarily due to variability in different lots of synthetic and recombinant $A \beta$, both within and among laboratories. Modifications in the $A \beta$ synthetic and purification protocols may affect its conformational and fibrillogenic properties [21,22]. The presence of impurities may alter $\mathrm{A} \beta$ kinetics of aggregation [23] and different storage conditions may also result in $\mathrm{A} \beta$ chemical modifications [24]. Although serious efforts have been invested 
in addressing these problems [25, 26], a reliable assay was highly desirable at this point.

Electrospray-ionization mass spectrometry (ESI-MS) is an established technique for detecting noncovalent protein/LMW molecules complexes [27-29]. Studies of such complexes between specific LMW compounds and $\mathrm{A} \beta$ have been reported previously by other groups [30-33] and us [34-36]. One debate in using ESI-MS is whether or not the detected gas-phase complex maintains a structural resemblance to the solution-phase complex. Although ESI-MS does not give insight into the three dimensional structure of the complex, reasonable agreements have been found between gas-phase and solution-phase binding affinities [27]. However, in source collisions can lead to the disruption of weaklybound complexes. On the other hand, droplet cooling due to the evaporation of solvent can lead to an apparent enhanced binding of the gas-phase complex and the formation of higher order complexes which were not pre-existing in the solution phase [37]. NanosprayESI-MS has been shown to better represent the solutionphase complex because smaller droplets undergo less dissolvation [38, 39]. For these reasons, it is very difficult to determine absolute solution-phase binding thermodynamics from the mass spectrum. However, if care is taken to maintain constant solution properties $(\mathrm{pH}$, salt content, and low analyte concentrations) as well as constant ESI source parameters, the observed trends in binding between analytes and the target peptide observed in ESI mass spectra will be consistent with those in solution [40].

The scope of this study is focused on the application of an efficient and reproducible moderate throughput ESI-MS screening method for the ranking of the binding affinity (BA) of a library of LMW compounds to A $\beta 1-42$, $A \beta 1-40$, and $A \beta 1-28$. The role of side-chain charge is investigated by substitution of charged amino acids by neutral amino acids on the $\mathrm{A} \beta 1-28$ sequence. Recent literature reported the effect of pyroglutamate-modified N-terminal truncated $\mathrm{A} \beta$ (A $\beta 3 \mathrm{pE}-40)$ to influence the oligomerization process [41] and to induce learning impairment as well as neuronal apoptosis [42]. Due to the increasing interest, we also investigated the BA of LMW compounds to this peptide. Finally, we discuss the peptidebinding characteristics of homotaurine, a natural product [43, 44] for the potential treatment of AD [45].

\section{Experimental}

\section{Materials}

$\mathrm{A} \beta 1-28, \mathrm{~A} \beta 1-40, \mathrm{~A} \beta 1-42$, and $\mathrm{A} \beta 3 \mathrm{pE}-40$ peptides were purchased from rPeptide (Bogart, GA) and three additional peptides were synthesized in-house (Figure 1). LMW compounds were purchased from commercial sources or synthesized in-house (Table 1). Stock solution $(50 \mu \mathrm{M})$ of each peptide was prepared in $0.1 \%$ trifluoroacetic acid (TFA, in deionized $\mathrm{H}_{2} \mathrm{O}$ ), which helps minimize peptide self-assembly by maintaining

\author{
$1 \quad \begin{array}{llll}10 & 20 & 28\end{array}$ \\ $\mathrm{H}_{2} \mathrm{~N}$-DAEFRHDSGYEVHHQKLVFFA EDVGSNKGAIIGLMVGGVVIA-OH \\ A $\beta 1-42(4514 \mathrm{Da})$ \\ $\mathrm{H}_{2} \mathrm{~N}-\mathrm{D}$ AEFRHDSGYEVHHQKLVFFA EDVGSNKGAIIGLMVGGVV-OH \\ $\underline{\mathrm{A} \beta 1-40(4330 \mathrm{Da})}$ \\ $\mathrm{H}_{2} \mathrm{~N}-\mathrm{DAEFRHDSGYEVHHQKLVFFA} \mathrm{EDVGSNK-OH}$ \\ A $\beta 1-28(3263 \mathrm{Da})$ \\ $\mathrm{H}_{2} \mathrm{~N}$-GASFGHASGYEVHHQELVFFA ESVGSNS-NH2 \\ all (-) peptide (2950Da) \\ $\stackrel{+}{\mathrm{H}_{2} \mathrm{~N}-\text { GASFRHASGYSVHHQKLVFFASAVGSN }} \stackrel{+}{\mathbf{K}-\mathrm{NH}_{2}}$ \\ all $(+)$ peptide $(2989 \mathrm{Da})$ \\ pyro-FRHDSGYEVHHQKLVFFA EDVGSNKGAIIGLMVGGVV-OH \\ A $33 \mathrm{pE}-40(4126 \mathrm{Da})$
}

Figure 1. Peptides used in the study. The numbers on top represent the amino acid number in the sequence. The plus "+" and minus "-" signs represent the positive or negative charge, respectively in its side chain at physiological $\mathrm{pH}$. Each peptide sequence is followed by its name and molecular weight in parentheses.

the N-terminal part as an $\alpha$-helix [46, 47]. Each stock solution was then sonicated for $5 \mathrm{~min}$. To determine the binding affinity (BA) of LMW compounds, a stock solution of $\mathrm{A} \beta$ peptide was mixed with a compound solution in deionized $\mathrm{H}_{2} \mathrm{O}$ to obtain a test solution with final concentrations of $30 \mu \mathrm{M}$ and $150 \mu \mathrm{M}$ for the peptide and the compound, respectively [34, 36]. The $\mathrm{pH}$ of the test solution was adjusted to $7.4 \pm 0.2$ using $0.1 \% \mathrm{NaOH}$ and a Beckman (Mississauga, Canada) Ф35 $\mathrm{pH}$ meter equipped with a Corning semi-micro combination $\mathrm{pH}$ electrode.

\section{ESI-M Analysis}

ESI-MS measurements were performed on a Waters ZQ 4000 mass spectrometer equipped with a Waters 2795 sample manager (Waters, Manchester, England). MassLynx 4.1 was employed for data processing and analysis. The sample solutions were injected in the ESI-MS using a mobile phase composed of $95 \% \mathrm{H}_{2} \mathrm{O}$ and $5 \%$ ethanol at a flow rate of $150 \mu \mathrm{L} \cdot \min ^{-1}$. A $2 \mu \mathrm{L}$ air gap was drawn before and after the compound-peptide mixture so that the mobile phase was not in contact with the sample. The desolvation temperature was set to $150{ }^{\circ} \mathrm{C}$ while the source temperature was maintained at $90^{\circ} \mathrm{C}$. The desolvation and nebulization gases were both set to $300 \mathrm{~mL} / \mathrm{min}$. The cone and capillary voltages were kept at $18 \mathrm{~V}$ and $3.2 \mathrm{kV}$, respectively. All mass spectra were sums of 300 scans $(0.9$ scan/s, inter-scan delay of $0.1 \mathrm{~s})$ from 100 to $2000(\mathrm{~m} / \mathrm{z})$ in the positive mode.

\section{Results and Discussion}

$\mathrm{A} \beta 1-40$ and $\mathrm{A} \beta 1-42$ peptides share an identical amino acid (AA) sequence except for two AA residues, Ile and 
Table 1. Compounds used in the study

\begin{tabular}{|c|c|c|c|}
\hline No. & Structure ${ }^{a}$ & M.W. & Name(s) [CAS] \\
\hline 1 & O & 237.3 & $\begin{array}{l}\text { 3-Cyclohexylamino-2-hydroxy-1-propanesulfonic acid; CAPSO } \\
\text { [73463-39-5] }\end{array}$ \\
\hline 2 & & 225.3 & 3-(1-Hydroxy-2-pentyl)amino-1-propanesulfonic acid [720699-42-3] \\
\hline 3 & & 139.2 & 3-Amino-1-propanesulfonic acid; homotaurine; Vivimind [3687-18-1] \\
\hline 4 & & 165.2 & 3-Amino-3-phenylpropanoic acid [103-01-5] \\
\hline 5 & & 139.1 & 3-Aminopropyl-1-phosphonic acid [13138-33-5] \\
\hline 6 & & 103.1 & 4-Aminobutyric acid; GABA [56-12-2] \\
\hline 7 & & 73.1 & n-Butylamine [109-73-9] \\
\hline 8 & & 138.2 & 1-Butanesulfonic acid [2386-47-2] \\
\hline 9 & & 140.2 & 3-Hydroxy-1-propanesulfonic acid [15909-83-8] \\
\hline 10 & & 204.2 & 1,3-propanedisulfonic acid; Eprodisate; Kiacta [13881-91-9] \\
\hline 11 & & 125.2 & 2-Aminoethanesulfonic acid; taurine [2386-47-2] \\
\hline 12 & & 153.2 & 4-Amino-1-butanesulfonic acid [14064-34-7] \\
\hline 13 & & 167.2 & 5-Amino-1-pentanesulfonic acid [37043-68-8] \\
\hline 14 & & 181.2 & 6-Amino-1-hexanesulfonic acid [72372-71-5] \\
\hline
\end{tabular}

aOnly non-salt forms are given. Some compounds were sodium salt forms. 
Table 2. Binding affinity (eq 1 ) for Compounds $1-4$ with $\mathrm{A} \beta 1$ $42, \mathrm{~A} \beta 1-40$, and $\mathrm{A} \beta 1-28$

\begin{tabular}{cccr}
\hline & \multicolumn{3}{c}{$\mathrm{BA}(\%)$} \\
\cline { 2 - 4 } Compound no. & $\mathrm{A} \beta 1-42$ & $\mathrm{~A} \beta 1-40$ & $\mathrm{~A} \beta 1-28$ \\
\hline \hline 1 & $54 \pm 3$ & $49 \pm 1$ & $49 \pm 1$ \\
2 & $38 \pm 2$ & $43 \pm 2$ & $41 \pm 4$ \\
3 & $28 \pm 3$ & $33 \pm 1$ & $33 \pm 3$ \\
4 & $14 \pm 1$ & $13 \pm 1$ & $9 \pm 1$ \\
\hline
\end{tabular}

Ala, added to the C-terminal end of the latter (Figure 1). A $\beta 1-28$ peptide is a $C$-terminal-truncated version of the A $\beta 1-40 / 42$ peptides containing only the first 28 AA residues from the $\mathrm{N}$-terminal. The $\mathrm{C}$-terminal part of the A $\beta 1-40 / 42$ peptides (AA 29-40/42) is the hydrophobic part. All charged or polar side chains are located in the first 28 residues of the $\mathrm{N}$-terminal. The charge distribution in the peptides has a unique pattern: a positive charge following two negative charges at $\mathrm{pH}$ $7.4 \pm 0.2$ (assuming that histidines remain uncharged under such conditions). The charge motif is repeated three times from residue 1 (D) to residue $28(\mathrm{~K})$. Under experimental conditions at physiologic $\mathrm{pH}$, the mass spectra of the three peptides $(\mathrm{A} \beta 1-42, \mathrm{~A} \beta 1-40$, and A $\beta 1-28$ ) show typical peaks corresponding to species having four and five positive charges. In certain cases, a three positive charge region is visible as well. Each charged species appears as a peak cluster due to the various number of sodium ions associated to the peptide. Consequently, when a LMW compound is bound to a peptide, the noncovalent complex also appears as a peak cluster at the corresponding $m / z$ ratio, due to the association of the complex with various numbers of sodium ions. To evaluate the BA of a compound to the $\mathrm{A} \beta$ peptide, the following equation was used:

$$
B A(\%)=\frac{\sum \text { complex peaks height }}{\sum(\text { peptide peaks heights }}+100
$$

In eq 1 , the sums are over all ionic species present in the mass spectrum for the complex or peptide (all peaks have the same widths). For purposes of reproducibility, the average binding (mean \pm SD) was calculated from
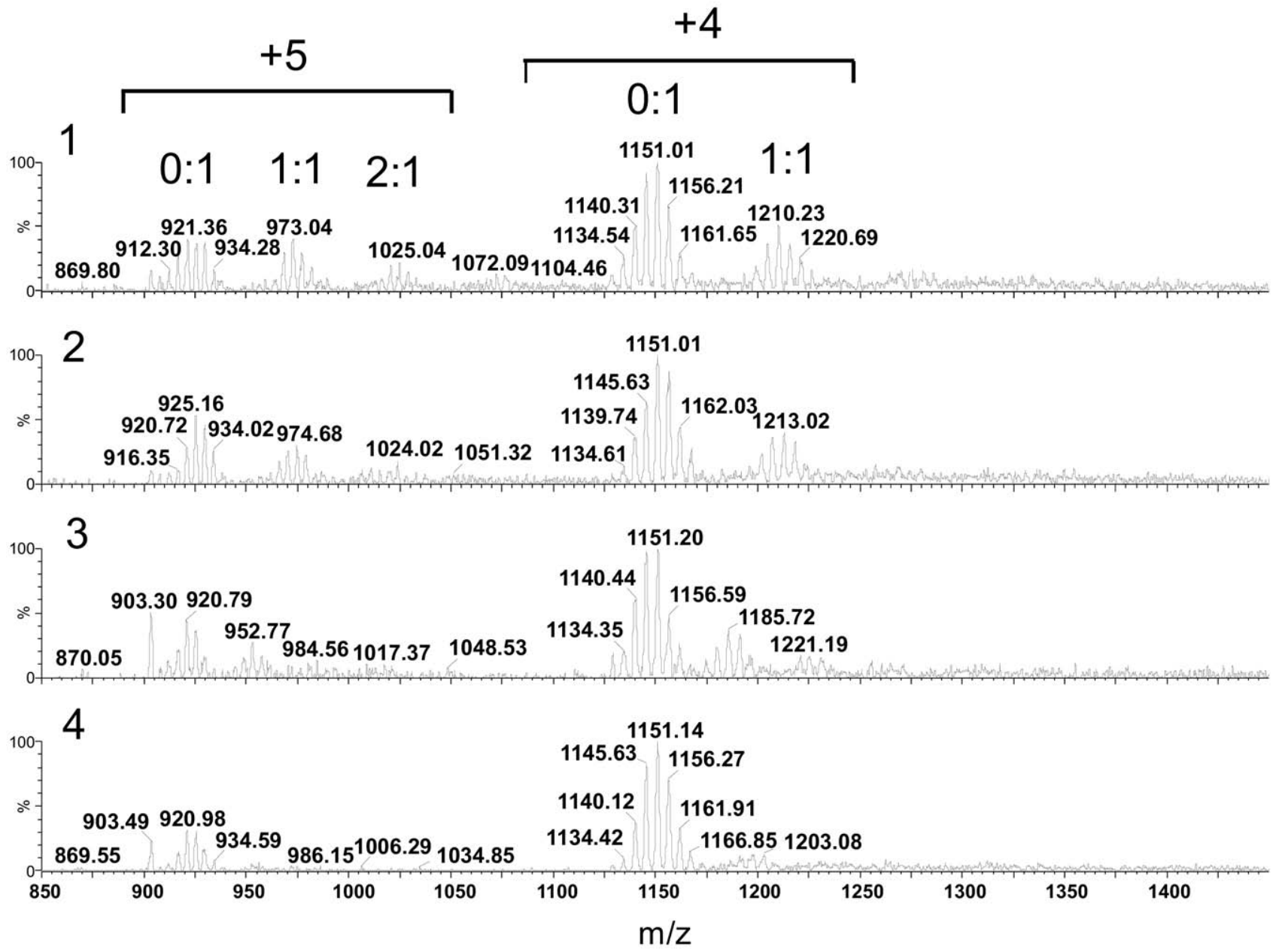

Figure 2. Binding profiles of Compounds 1-4 to A $\beta 1-42 .+5$ and +4 charge regions denoted, along with peak clusters due to the protonated peptide $(0: 1), 1: 1$ compound:peptide complex and 2:1 compound:peptide complex. 
Table 3. Binding affinity (eq 1) for Compounds $1-4$ with peptides of different charge motif

\begin{tabular}{crrc}
\hline & \multicolumn{3}{c}{ BA (\%) } \\
\cline { 2 - 4 } Compound no. & A $\beta 1-28$ (native) & all (-) & all (+) \\
\hline \hline 1 & $49 \pm 1$ & $35 \pm 2$ & $30 \pm 2$ \\
2 & $41 \pm 4$ & $33 \pm 3$ & $24 \pm 1$ \\
3 & $33 \pm 3$ & $16 \pm 2$ & 0 \\
4 & $9 \pm 1$ & $6 \pm 1$ & 0 \\
\hline
\end{tabular}

six measurements. For a result to be accepted, $\mathrm{SD} \leq$ $10 \%$ was required. Other groups have developed methods to calculate an association constant $\left(\mathrm{K}_{\mathrm{A}}\right)[39,48,49]$. Although more accurate, the calculation of $\mathrm{K}_{\mathrm{A}}$ can be time-consuming for a first-line screening method. It is worth mentioning that our assay uses much less compound and peptide to observe complex formation than in a method previously described [32]. Previously, we have shown [34] that the maximum BA between a given compound and the $\mathrm{A} \beta 1-40$ peptide rises from $\mathrm{pH} 1$ to approximately $\mathrm{pH} 6$ and then decreases with further increase of $\mathrm{pH}$. Hence, the maximum $\mathrm{BA}$ is close to the physiological $\mathrm{pH}$. In this assay, the $\mathrm{A} \beta 1-40$ peptide was selected over the $A \beta 1-42$ and $A \beta 1-28$ peptides for two reasons: first, the $\mathrm{A} \beta 1-40$ peptide is less prone to aggregation and has a better water solubility than the A $\beta 1-42$ peptide [11] and second, it contains a Cterminal hydrophobic region (absent in the $A \beta 1-28$ peptide), which makes it more physiologically relevant. To further justify the selection of the $A \beta 1-40$ peptide for this assay, it was required to verify if this peptide could differentiate the binding strength of various compounds and if the BA ranking order remained consistent whichever peptide $(\mathrm{A} \beta 1-28, \mathrm{~A} \beta 1-40$, or $\mathrm{A} \beta 1-42)$ was used. Table 2 summarizes the binding results between representative compounds and the three $\mathrm{A} \beta$ peptides.

For visual examination of binding complexes, Figure 2 compares the binding profiles of the four selected compounds to the $\mathrm{A} \beta 1-42$ peptide. The $m / z$ region from 900 to 1125 contains the peak-clusters of the peptide and the complexes bearing five positive charges ( +5 region). The $m / z$ region from 1125 to 1400 contains the species having four positive charges ( +4 region). The $\mathrm{m} / \mathrm{z}$
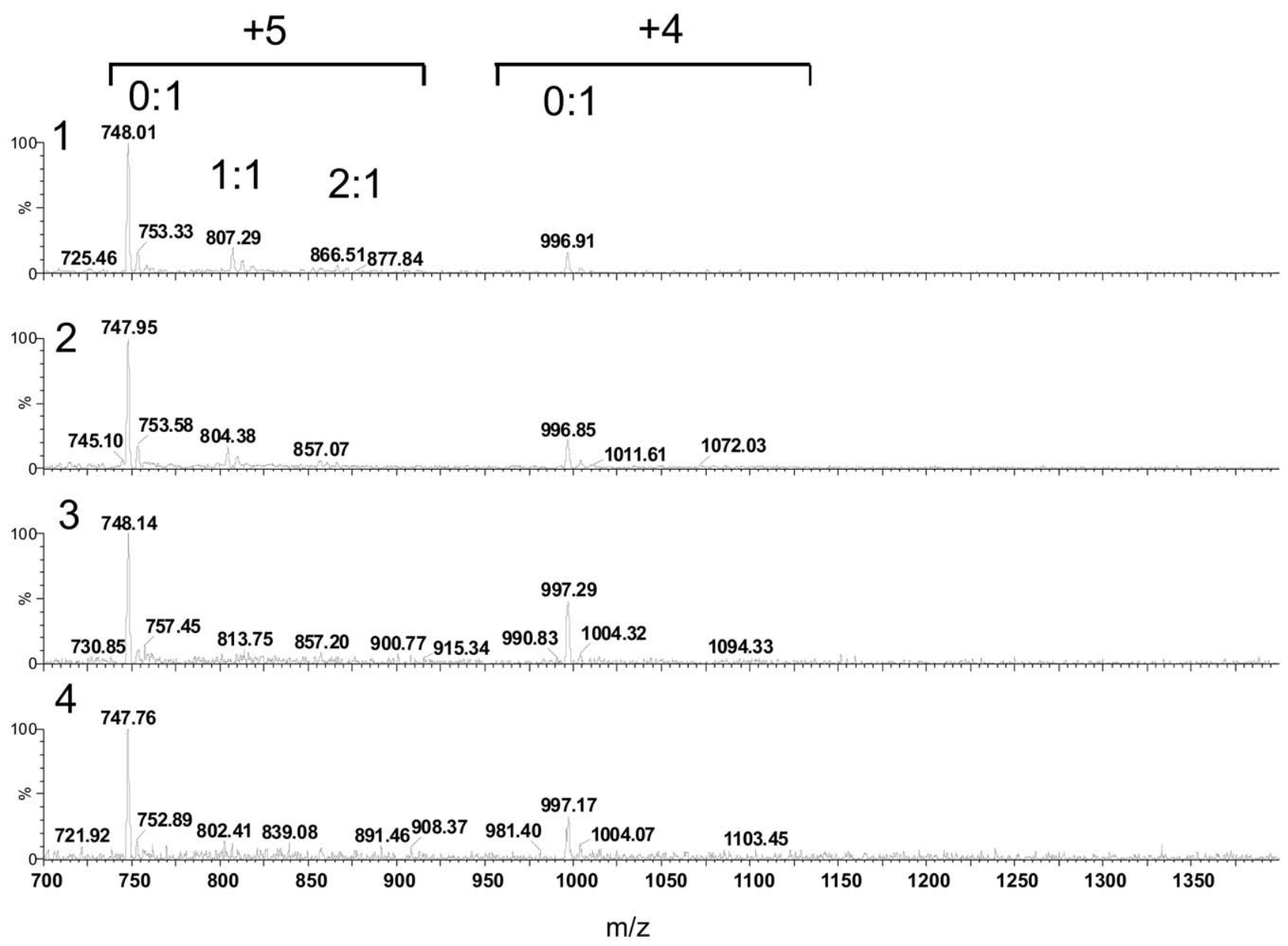

Figure 3. Binding profiles of Compounds 1-4 to the all $(+)$ peptide. +5 and +4 charge regions denoted, along with peak clusters due to the protonated peptide (0:1), 1:1 compound:peptide complex and 2:1 compound:peptide complex. 


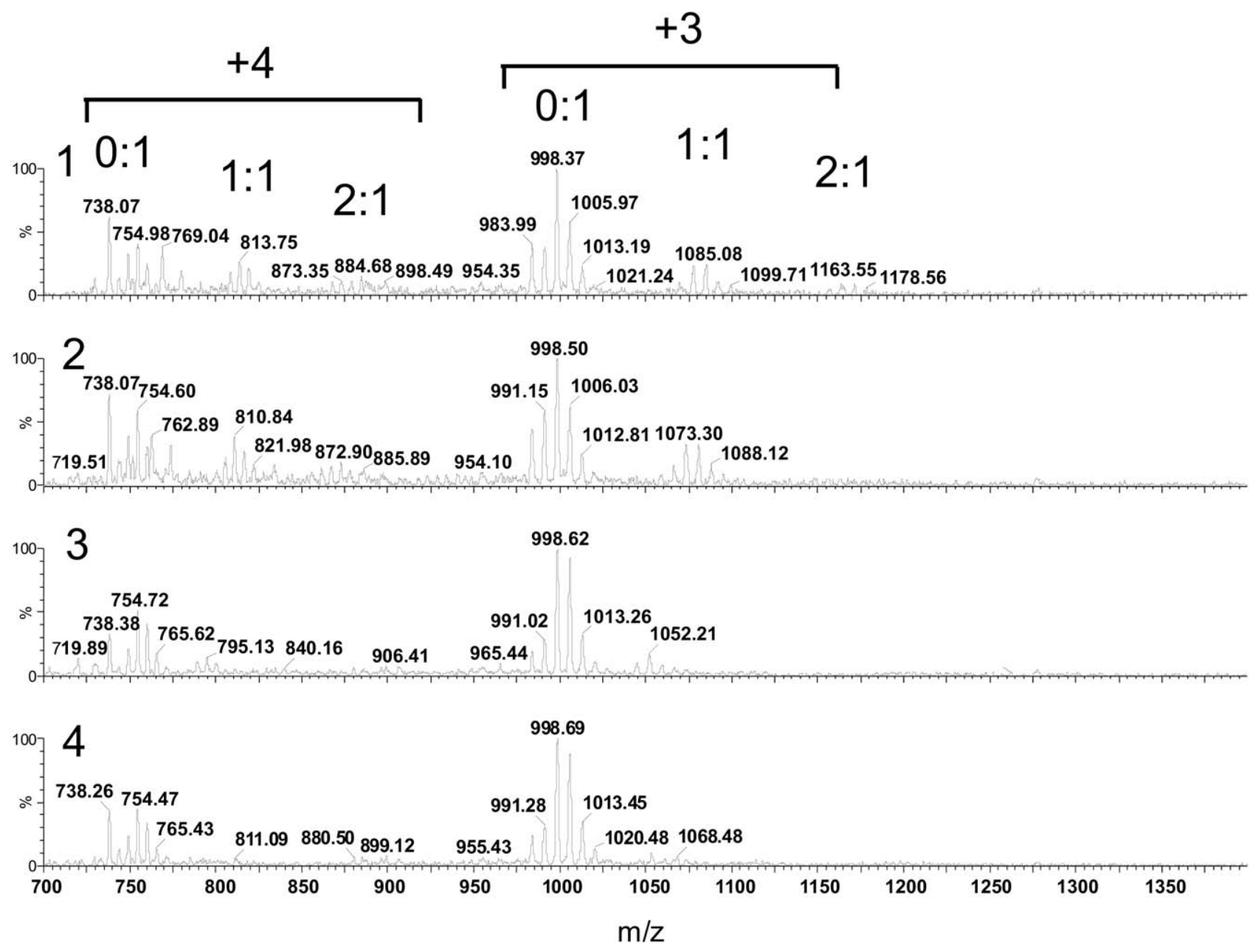

Figure 4. Binding profiles of Compounds 1-4 to the all $(-)$ peptide. +5 and +4 charge regions denoted, along with peak clusters due to the protonated peptide (0:1), 1:1 compound:peptide complex and 2:1 compound:peptide complex.

region corresponding to species having three positive charges ( +3 region) is not shown on the spectra. On all mass spectra, the peak-clusters centered approximately at $m / z=925,1151$, and 1526 (not shown) are the free peptides having $+5,+4$, and +3 charges, respectively. In each region, to the right side of the free peptide peak cluster are the 1:1 compound-peptide complex (first peak cluster), the 2:1 compound-peptide complex (second peak cluster), and the 3:1 compound-peptide complex (third peak cluster). This observation indicates, at least in some cases, that more than one molecule of a compound can bind to one peptide ion. Employing the intensities of each peak in eq 1 allows the calculation of BA. Compounds in Table 2 represent four different categories (strong, BA $>45 \%$; moderate, $35 \leq \mathrm{BA}<$ $45 \%$; weak, $20 \leq \mathrm{BA}<35 \%$, and non-binding, $\mathrm{BA}<$ $20 \%$ ). One aspect of ESI that hinders the quantitative assignment of the BA in solution is the tendency to form noncovalent complexes in the gas-phase during the electrospray process. The compounds in Table 2 are all structurally similar and thus differences between solution and gas-phase behavior should also be conserved across the compound library, making comparisons meaningful.

As shown in Table 2, the BA ranking order remains the same for each given compound to all three peptides. Furthermore, the "absolute binding affinity" (as measured in binding percentage) for a specific compound is similar when tested against all three peptides. These observations indicate that the C-terminal hydrophobic part of the $\mathrm{A} \beta$ peptide does not play a significant role in binding these LMW compounds, suggesting therefore that the N-terminal part is mostly responsible for the noncovalent binding. The noncovalent complex formation occurs through dipole-dipole or charge-charge interactions [50]. In this assay, we have chosen to use A $\beta 1-40$ as the peptide for screening purposes since it is the least expensive.

During method development, another important consideration was given to ensure that these low structural complexity compounds were binding specifically to $\mathrm{A} \beta$ peptides and not to any peptide in general. At physiologic $\mathrm{pH}$, the N-terminal sequence of the $\mathrm{A} \beta$ peptide possesses a specific charge motif, which may 
Table 4. Binding affinity (eq 1) for Compounds 1-4 with $\mathrm{A} \beta 3 \mathrm{pE}-40$ and $\mathrm{A} \beta 1-40$ in $20 \%$ ethanol

\begin{tabular}{ccc}
\hline & \multicolumn{2}{c}{ BA in 20\% ethanol (\%) } \\
\cline { 2 - 3 } Compound no. & $\mathrm{A} \beta 1-40$ & $\mathrm{~A} \beta 3 \mathrm{pE}-40$ \\
\hline \hline 1 & $57 \pm 1$ & $49 \pm 1$ \\
2 & $52 \pm 1$ & $39 \pm 1$ \\
3 & $37 \pm 1$ & $30 \pm 2$ \\
4 & $22 \pm 1$ & $15 \pm 1$ \\
\hline
\end{tabular}

play an important role in the peptide binding to LMW compounds. To test this hypothesis, two peptides (all $(-)$, all (+), each having 28 AA residues; see Figure 1) were synthesized and studied for their binding behavior. At physiologic pH the "all (-) peptide" has three negatively charged residues in the sequence and no positive charges (except for the $\mathrm{N}$-terminal residue) and the "all (+) peptide" has three positively charged residues. Table 3 compares the BA of Compounds 1-4 with these two peptides and A $\beta 1-28$. When comparing the BA of Compounds 1-4 with all three peptides having 28-AA residues, the most striking observation is that none of them bind significantly to the all $(+)$ peptide (Figure 3). One important feature of the mass spectra is the absence of sodium cluster peaks for this system because there are no side chains charged negatively under experimental conditions. In the all $(+)$ peptide, all these AA residues have been substituted by neutral ones; thus, there may be one (or a very few) sodium cations that are bound to the species present on these mass spectra.

Figure 4 shows the binding profile of the four compounds to the all (-) peptide. The peak-cluster centered at $m / z 755$ represents the free peptide having four positive charges, whereas the one at $\mathrm{m} / \mathrm{z} 999$ is the +3 charged species of the peptide. In this case, the BA was decreased by at least $25 \%$ with all four compounds compared with the native peptide. Interestingly, the decrease of the BA is not proportional to the lower number of negative charges in the peptide. When comparing observations made with the all $(+)$ peptide, it may be concluded that binding of these compounds is
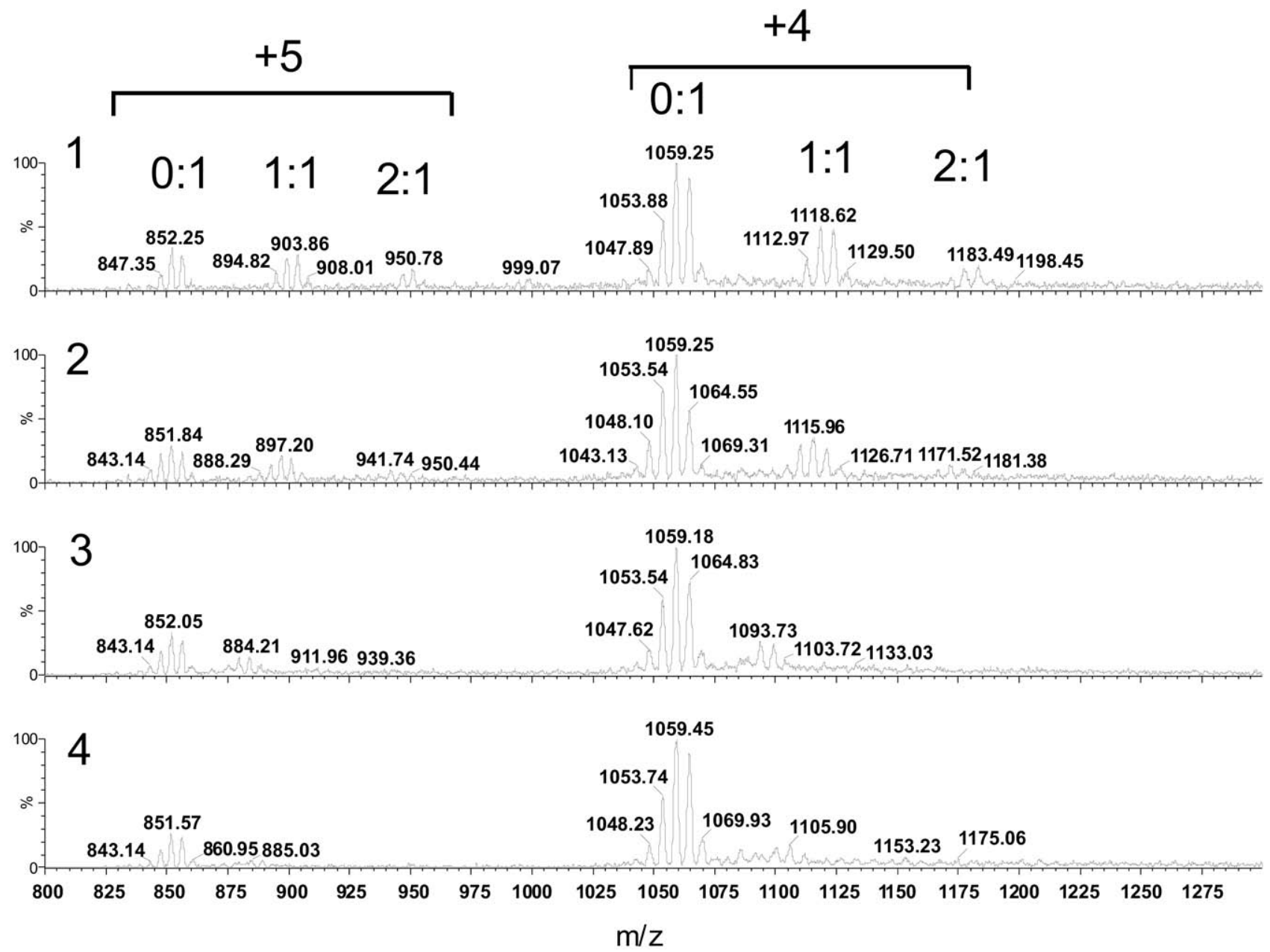

Figure 5. Binding profiles of Compounds 1-4 to the $\mathrm{A} \beta 3 \mathrm{pE}-40 .+5$ and +4 charge regions denoted, along with peak clusters due to the protonated peptide (0:1), 1:1 compound:peptide complex and 2:1 compound:peptide complex. 
Table 5. Effect of replacing the sulfonic group on the binding affinity (eq 1) with $\mathrm{A} \beta 1-40$

\begin{tabular}{ccc}
\hline Compound no. & $\mathrm{H}_{2} \mathrm{~N}-\left(\mathrm{CH}_{2}\right)_{3}-\mathrm{R}$ & $\mathrm{BA}$ to $\mathrm{A} \beta 1-40(\%)$ \\
\hline \hline 3 & $-\mathrm{SO}_{3} \mathrm{H}$ & $33 \pm 1$ \\
5 & $-\mathrm{PO}_{3} \mathrm{H}_{2}$ & $24 \pm 1$ \\
6 & $-\mathrm{CO}_{2} \mathrm{H}$ & 0 \\
7 & $-\mathrm{CH}_{3}$ & 0 \\
\hline
\end{tabular}

dominantly mediated by the negatively-charged side chains in the $\mathrm{A} \beta$ peptide.

The BA of the A $\beta 1-40$ peptide with Compounds 1-4 was compared with their binding with the $\mathrm{A} \beta 3 \mathrm{pE}-40$ peptide under exactly same conditions. A $\beta 3 p E-40$ was shown to be very amyloidogenic and could potentially initiate the amyloid aggregation process. Due to the low solubility of $\mathrm{A} \beta 3 \mathrm{pE}-40$ in aqueous media, experiments for both peptides were performed in a mixture of water $(80 \%)$ and ethanol $(20 \%)$. The data are summarized in Table 4 and the mass spectra are given in Figure 5. As shown in Table 4, the BA with the A $\beta 1-40$ peptide increases by $5 \%$ to $10 \%$ for Compounds 1-4 when the solvent contains $20 \%$ ethanol. Their BA with the A $\beta 3 p E-40$ peptide was $\sim 5 \%$ to $10 \%$ lower compared to $\mathrm{A} \beta 1-40$, but the ranking order stayed the same. The lower BA with the A $\beta 3 \mathrm{pE}-40$ peptide might be due either to removal of two negative charges from the $\mathrm{N}$-terminal or to disappearance of a charge motif after the N-terminal truncation of $A \beta 1-40$ peptide.

Effort was also directed to the structure-activity relationship (SAR) for binding of the A $\beta 1-40$ peptide with LMW compounds. Homotaurine (Compound 3, Vivimind) aims at targeting soluble $\mathrm{A} \beta$ peptide and was used as a reference point for comparing the effect of each component in the structure: the amino group, the sulphonate group, and the alkyl spacer in between. Table 5 reports the effect of different substitutions on the sulfonic group. None of the substitutions shown in Table 5 is advantageous to maintain BA. Only the phosphonate substituent retained significant binding. It is important to mention here that GABA, a bioisostere of homotaurine and an important neurotransmitter present in the human brain, does not bind at all to soluble A $\beta 1-40$ peptide. Table 6 reports the effect of amine substitution of Compound 3. Again in this case, none of the reported substitutions was advantageous to maintain BA. Only methyl substitution was able to preserve some binding. Eprodisate (Compound 10), an investigational clinical drug candidate targeting serum amyloid A [51], is selective for this peptide and does not

Table 6. Effect of replacing the amino group on the binding affinity (eq 1) with $\mathrm{A} \beta 1-40$

\begin{tabular}{ccc}
\hline Compound no. & $\mathrm{R}-\left(\mathrm{CH}_{2}\right)_{3}-\mathrm{SO}_{3} \mathrm{H}$ & $\mathrm{BA}$ to $\mathrm{A} \beta 1-40(\%)$ \\
\hline \hline 3 & $-\mathrm{NH}_{2}$ & $33 \pm 1$ \\
8 & $-\mathrm{CH}_{3}$ & 26 \\
9 & $-\mathrm{OH}_{2}$ & 0 \\
10 & $-\mathrm{SO}_{3} \mathrm{H}$ & 0 \\
\hline
\end{tabular}

Table 7. Effect of changing the length of the methylene group spacer chain on the binding affinity (eq 1) with $A \beta 1-40$

\begin{tabular}{ccc}
\hline Compound no. & $\mathrm{H}_{2} \mathrm{~N}-\left(\mathrm{CH}_{2}\right)_{\mathrm{n}}-\mathrm{SO}_{3} \mathrm{H}$ & $\mathrm{BA}$ to $\mathrm{A} \beta 1-40(\%)$ \\
\hline \hline 11 & $n=2$ & $29 \pm 2$ \\
3 & 3 & $33 \pm 1$ \\
12 & 4 & $30 \pm 3$ \\
13 & 5 & $29 \pm 1$ \\
14 & 6 & $27 \pm 2$ \\
\hline
\end{tabular}

bind to the A $\beta 1-40$ peptide. Finally, the length of the alkyl spacer was investigated using five different chain spacers tested against the A $\beta 1-40$ peptide (Table 7). The alkyl spacer does not play a significant role in maintaining $\mathrm{BA}$ to the $\mathrm{A} \beta 1-40$ peptide, although it seemed that the homotaurine three-carbon spacer between amino and sulphonate groups was optimal. The lack of sensitivity of BA to the length of the carbon spacer might be due to the flexibility of the linear structure in such simple compounds. Altogether, this information on the binding components of homotaurine shows that even though it is not a strong binder to $\mathrm{A} \beta$ peptides, it contains key elements to be considered as an antiamyloid agent. The mechanism of action of homotaurine for the treatment of $\mathrm{AD}$ has been extensively studied, in vitro and in vivo, and results will be reported separately.

\section{Conclusion}

An efficient and reproducible ESI-MS binding assay was developed for semiquantitative evaluation of the binding affinity of LMW compounds to $\mathrm{A} \beta$ peptides. The assay proved to be consistent on the binding affinity (BA) ranking from one peptide to another when comparing the noncovalent complexes formed with the same set of four compounds with $A \beta 1-28 / 40 / 42$. This allowed the use of peptide $\mathrm{A} \beta 1-40$ in this first-line screening assay. It was demonstrated that mutation or scrambling of the $A \beta$ peptide sequence affects the BA of the four targeted LMW compounds with the peptides. A similar effect was observed when the four LMW compounds were tested against $\mathrm{A} \beta 3 \mathrm{pE}-40$. The results indicate that the binding between $\mathrm{A} \beta$ and a LMW compound is likely through charge-charge interaction, and the negative charge motifs in the peptide are important to such. The results obtained using this assay indicated that homotaurine contains the necessary molecular properties for its binding to the soluble $A \beta$ peptide, and could interfere with the amyloidogenic cascade. In this study, BA obtained with the assay can be used as the first-line screening to select LMW compounds for further testing in biological assays.

\section{Acknowledgments}

The authors thank Nigel Levens and Diane Lacombe for providing useful comments on this manuscript. 


\section{References}

1. Wisniewski, H. M.; Wegiel, J. The Neuropathology of Alzheimer's Disease. Neuroimag. Clin. N. Am. 1995, 5, 45-57.

2. Esiri, M. M. The Neuropathology of Alzheimer's Disease. In: Neurobiology of Alzheimer's Disease, 2nd ed., Dawbarn, D.; Allen, S. J., Eds.; Oxford University Press: Oxford, England, 2001; p. 33-53.

3. Clark, C. M.; Karlawish, J. H. Alzheimer's Disease: Current Concepts and Emerging Diagnostic and Therapeutic Strategies. Ann. Intern. Med. 2003, 138, 400-410.

4. Hardy, J.; Selkoe, D. J. The Amyloid Hypothesis of Alzheimer's Disease: Progress and Problems on the Road to Therapeutics. Science 2002, 297, 353-356.

5. Hardy, J. A.; Higgins, G. A. Alzheimer's Disease: The Amyloid Cascade Hypothesis. Science 1992, 256, 184-185.

6. Wolfe, M. S. Secretase Targets for Alzheimer's Disease: Identification and Therapeutic Potential. J. Med. Chem. 2001, 44, 2039-2060.

7. Selkoe, D. Towards a Comprehensive Theory for Alzheimer's Disease. Hypothesis: Alzheimer's Disease is Caused by Cerebral Accumulation and Cytotoxicity of Amyloid- $\beta$-Protein. Ann. NY Acad. Sci. 2000, 924, $17-25$.

8. Sambamurti, K.; Greig, N. H.; Lahiri, D. K. Advances in the Cellular and Molecular Biology of the $\beta$-Amyloid Protein in Alzheimer's Disease. Neuromol. Med. 2002, 1, 1-31.

9. Barghorn, S.; Nimmrich, V.; Striebinger, A.; Krantz, C.; Keller, P.; Janson, B.; Bahr, M.; Schmidt, M.; Bitner, R. S.; Harlan, J.; Barlow, E.; Ebert, U.; Hillen, H. Globular Amyloid $\beta$-peptide oligomer-a Homogeneous and Stable Neuropathologic Protein in Alzheimer's Disease. I. Neurochem. 2005, 95, 834-847.

10. Jarrett, J. T.; Berger, E. P.; Lansbury P. T. Jr. The Carboxy Terminus of the $\beta$ Amyloid Protein is Critical for the Seeding of Amyloid Formation: Implications for the Pathogenesis of Alzheimer's Disease. Biochemistry 1993, 32, 4693-3697.

11. Vetrivel, K. S.; Thinakaran, G. Amyloidogenic Processing of $\beta$-Amyloid Precursor Protein in Intracellular Compartments. Neurology 2006, 66, S69-S73.

12. Chen, Y.; Glabe, C. G. Distinct Early Folding and Aggregation Properties of Alzheimer's Amyloid- $\beta$ Peptides A $\beta 40$ and A $\beta 42$. J. Biol. Chem. 2006, 281, 24414-24422.

13. Klein, W. L.; Krafft, G. A.; Finch, C. E. Targeting Small A $\beta$ Oligomers: The Solution to an Alzheimer's Disease Conundrum? Trends Neurosci. 2001, 24, 219-224.

14. Heneka, M. T. Inflammation in Alzheimer's Disease. Clin. Neurosci. Res. 2006, 6, 247-260.

15. Kisilevsky, R.; Fraser, P. E. A $\beta$ Amyloidogenesis: Unique, or Variation on a Systematic Theme? Crit. Rev. Biochem. Mol. Biol. 1997, 32, 361-404.

16. Verbeek, M. M.; Otte-Holler, I.; van den Born, J.; van den Heuvel, L. P. David, G.; Wesseling, P.; Waal, R. M. Agrin is a Major Heparan Sulfate Proteoglycan Accumulating in Alzheimer's Disease Brain. Am. J. Pathol. 1999, 155, 2115-2125.

17. Kisilevsky, R.; Lemieux, L. J.; Fraser, P. E.; Kong, X.; Hultin, P. G.; Szarek, W. A. Arresting Amyloidosis In Vivo Using Small-Molecule Anionic Sulphonates or Aulphates: Implications for Alzheimer's Disease. Nat. Med. 1995, 1, 143-148.

18. Gupta-Bansal, R.; Frederickson, R. C. A.; Bruden, K. R. ProteoglycanMediated Inhibition of $A \beta$ Proteolysis: a Potential Cause of Senile Plaque Accumulation. J. Biol. Chem. 1995, 270, 18666-18671.

19. Levine, H. III. Thioflavin T interaction with Alzheimer's Disease $\beta$-Amyloid Peptides: Detection of Amyloid Aggregation in Solution. Protein Sci. 1993, 3, 404-410.

20. Wang, S. S.; Chen, Y.-T.; Chou, S.-W. Inhibition of Fibril Formation of $\beta$-Amyloid Peptides Via the Amphiphilic Surfactants. Biochim. Biophys. Acta 2005, 1741, 307-313.

21. Kaneko, I.; Tutumi, J. Matters Arising: Conformations of $\beta$-Amyloid in Solution. J. Neurochem. 1997, 68, 438-439.

22. Soto, C.; Castaño, E. M.; Kumar, R. A.; Beavis, R. C.; Frangione, B. Fibrillogenesis of Synthetic Amyloid- $\beta$ Peptides is Dependent on Their Initial Secondary Structure. Neurosci. Lett. 1995, 200, 105-108.

23. Hou, L.; Kang, I.; Merchant, R. E.; Zagorski, M. G. Methionine 35 Oxidation Reduces Fibril Assembly of the Amyloid A $\beta-(1-42)$ Peptide of Alzheimer's Disease. J. Biol. Chem. 2002, 277, 40173-40176.

24. Nilsson, M. R.; Driscoll, M. D.; Raleigh, D. P. Low Levels of Asparagine Deamidation Can Have a Dramatic Effect on Aggregation of Amyloidogenic Peptides: Implications for the Study of Amyloid Formation. Protein Sci. 2002, 11, 342-329.

25. Nilsson, M. Techniques to Study Amyloid Fibril Formation In Vitro. Methods 2004, 34, 151-160.

26. Eisert, R.; Felau, L.; Brown, L. R. Methods for Enhancing the Accuracy and Reproducibility of Congo Red and Thioflavin T Assays. Anal. Biochem. 2006, 353, 144-146.

27. Loo, J. A. Studying Noncovalent Protein Complexes by Electrospray Ionization Mass Spectrometry. Mass Spectrom. Rev. 1997, 16, 1-23.

28. Smith, R. D.; Light-Wahl, K. J. The Observation of Noncovalent Interactions in Solution by Electrospray Ionization Mass Spectrometry, Promise, Pitfalls, and Prognosis. Biol. Mass Spectrom. 1993, 22, 493-501.
29. Bruce, J. E.; Anderson, G. A.; Chen, R.; Chen, X.; Gale, D. C.; Hofstadler, S. A.; Schwartz, B. L.; Smith, R. D. Bio-Affinity Characterization Mass Spectrometry. Rapid Commun. Mass Spectrom. 1995, 9, 644-650.

30. Camilleri, P.; Haskins, N. J.; Howlett, D. R. $\beta$-Cyclodextrin Interacts with the Alzheimer's Amyloid $\beta$-A4 Peptide. FEBS Lett. 1994, 341, 256-258.

31. Skribanek, Z; Baláspiri, L: Mák, M. Interaction Between Synthetic Amyloid- $\beta$-Peptide (1-40) and Its Aggregation Inhibitors Studied by Electrospray Ionization Mass Spectrometry. J. Mass Spectrom. 2001, 36, 1226-1229.

32. Bazoti, F. N.; Tsarbopoulos, A.; Markides, K. E.; Bergquist, J. Study of the Noncovalent Interaction Between Amyloid- $\beta$-Peptide and Melatonin Using Electrospray Ionization Mass Spectrometry. J. Mass Spectrom. 2005, 40, 182-192

33. Cheng, X.; van Breemen, R. B. Mass Spectrometry-Based Screening for Inhibitors of $\beta$-Amyloid Protein Aggregation. Anal. Chem. 2005, 77, 7012-7015.

34. Martineau, E.; Aman, A. M.; Kong, X. pH Effect on the Association Between the Amyloid $\beta$ Peptide and Low Molecular Weight Molecules. 71e Congrès de l'Acfas, Rimouski, Qc, Canada, May 19-23, 2003.

35. Gervais, F.; Morissette, C.; Kong, X. Proteoglycans and Amyloidogenic Proteins in Peripheral Amyloidosis. Curr. Med. Chem. Immun. Endoc. Metab. Agents 2003, 3, 361-370.

36. Gervais, F.; Paquette, J.; Morissette, C.; Krzywkowski, P.; Yu, M.; Azzi, M.; Lacombe, D.; Kong, X.; Aman, A.; Laurin, J.; Szarek, W. A.; Tremblay, P. Targeting Soluble A $\beta$ with Tramiprosate for the Treatment of Brain Amyloidosis. Neurobiol. Aging 2007, 28, 537-547.

37. Busman, M.; Knapp, D. R.; Schey, K. L.; Smith, R. Observation of Large Multimers in the Electrospray Ionization Mass Spectrometry of Peptides. Rapid Commun. Mass Spectrom. 1994, 8, 211-216.

38. Benkestock, K.; Sundqvist, G.; Edlund, P. O.; Roeraade, J. Influence of Droplet Size, Capillary-Cone Distance, and Selected Instrumental $\mathrm{Pa}$ rameters for the Analysis of Noncovalent Protein-Ligand Complexes by Nano-Electrospray Mass Spectrometry. J. Mass Spectrom. 2004, 39, 1059-1067

39. Peschke, M.; Verkerk, U. H.; Kebarle, P. Features of the ESI Mechanism that Affect the Observation of Multiply Charged Noncovalent Protein Complexes and the Determination of the Association Constant by the Titration Method. J. Am. Soc. Mass Spectrom. 2004, 15, 1424-1434.

40. Hardouin, J.; Lange, C. M. Biological Noncovalent Complexes By Mass Spectrometry. Curr. Org. Chem. 2005, 9, 317-324.

41. Schilling, S.; Lauber, T.; Schaupp, M.; Manhart, S.; Scheel, E.; Böhm, G.; Demuth, H.-U. On the Seeding and Oligomerization of pGly-Amyloid Peptides (in vitro). Biochemistry 2006, 41, 12393-12399.

42. Youssef, I.; Florent-Béchard, S.; Malaplate-Armand, C.; Koziel, V.; Bihain, B.; Olivier, J.-L.; Leininger-Muller, B.; Kriem, B.; Oster, T.; Pillot, T. N-Truncated Amyloid- $\beta$ Oligomers Induce Learning Impairment and Neuronal Apoptosis. Neurobiol. Aging 2007, doi:10.1016/j.neurobiolaging 2007.03.005

43. Miyazawa, K.; Ito, K.; Matsumoto, F. Aminosulfonic Acids in Six Species of Marine Algae. Bull. Jpn. Soc. Sci. Fish. 1969, 35, 1215-1219.

44. Miyazawa, K.; Ito, K.; Matsumoto, F. Amino Acids Peptide in Seven Species of Marine Green Algae. J. Fac. Fish Anim. Husb. 1976, 15, 161-169.

45. Aisen, P. S.; Gauthier, S.; Vellas, B.; Briand, R.; Saumier, D.; Laurin, J.; Garceau, D. Alzhemed: A Potential Treatment for Alzheimer's Disease. Curr. Alz. Res. 2007, 4, 473-478.

46. Shen, C.-L.; Murphy, R. M. Solvent Effects on Self-Assembly of $\beta$-Amyloid Peptide. Biophys. J. 1995, 69, 640-651.

47. Talafous, J.; Marcinowski, K. J.; Klopman, G.; Zagorski, M. G. Solution Structure of Residue 1-28 of the Amyloid $\beta$-Peptide. Biochemistry 1994, 33, 7788-7796.

48. Wortmann, A.; Rossi, F.; Lelais, G.; Zenobi, R. Determination of zinc to beta-Peptide Binding Constants with Electrospray Ionization Mass Spectrometry. J. Mass Spectrom. 2005, 40, 777-784.

49. Wang, W.; Kitova, E. N.; Klassen, J. S. Influence of Solution Gas Phase Processes on Protein-Carbohydrate Binding Affinities Determined by Nanoelectrospray Fourier Transform Ion Cyclotron Resonance Mass Spectrometry. Anal. Chem. 2003, 75, 4945-4955.

50. Sun, J.; Kitova, E. N.; Wang, W.; Klassen, J. S. Method for Distinguishing Specific from Nonspecific Protein-Ligand Complexes in Nanoelectrospray Ionization Mass Spectrometry. Anal. Chem. 2006, 78, 3010-3018.

51. Dember, L. M.; Hawkins, P. N.; Hazenberg, M. D.; Bouke P. C.; Gorevic, P. D.; Merlini, G.; Butrimiene, I.; Livneh, A.; Lesnyak, O.; Puechal, X.; Lachmann, H. J.; Obicic, L.; Balshaw, R.; Garceau, D.; Hauck, W.; Skinner, M.; Bhargava, A.; Faragasso, A.; Levy, K.; Keown, P.; Kaarela K.; Grateau, G.; Hachulla, E.; Livneh, A.; Rosner, I.; Merlini, G.; Obici, L.; Butrimiene, I.; Kirdaite, G.; Povilenaite, D.; Venalis, A.; Bijzet, J.; Filipowicz-Sosnowska, A.; Wiland, P.; Chlebicki, A.; Lesnyak, O.; Koryakova, N.; Sibiryakova, A.; Nasonov, E. L.; Stanislav, M.; Jover, J. A.; Munoz, J.; Tena Marsa, X.; Valverde Garcia, J.; Ben Maiz, H.; Ben Mousa, F.; Goucha, R.; Kaaroud, H.; Direskeneli, H.; Temel, M.; Gul, A.; Kamali, S.; Hatemi, G.; Ozdogan, H.; Hawkins, P. N.; Lachman, H. J.; Hunter, J. A.; Benson, M. D.; Dispenzieri, A.; Gorevic, P. D. Eprodisate for the treatment of renal disease in AA amyloidosis. New Eng. J. Med. 2007, 356, 2349-2360. 